\title{
Mitonucleons
}

A new chapter in the story of mitochondria?

\begin{tabular}{|c|c|}
\hline $\begin{array}{l}\text { Mitonucleons are a } \\
\text { newly recognised type of } \\
\text { mitochondrial superstructure. } \\
\text { Consisting of multiple } \\
\text { mitochondria enveloping } \\
\text { chromatin, mitonucleons } \\
\text { appear to be responsible for } \\
\text { the development of unusual } \\
\text { structures called spheroids. } \\
\text { Dr Honoree Fleming of } \\
\text { Castleton State College, } \\
\text { Vermont, USA, has identified } \\
\text { mitonucleons in human } \\
\text { endometrial cells in vitro. } \\
\text { Using microscopy, Dr Fleming } \\
\text { has also observed mysterious } \\
\text { structures called tubules, } \\
\text { which appear to allow material, } \\
\text { including mitonucleons, to } \\
\text { move between cells. This } \\
\text { work could have important } \\
\text { implications for many aspects } \\
\text { of cell biology, including } \\
\text { cancer research. }\end{array}$ & $\begin{array}{l}\text { t might seem that some things } \\
\text { in science are so well-known that } \\
\text { there must be little left about them } \\
\text { to discover. Take mitochondria, for } \\
\text { example. These rod-shaped organelles, } \\
\text { the power generators of the cell, were } \\
\text { first observed by microscope in the } \\
\text { late } 19 \text { th century. Since then, they have } \\
\text { been intricately and comprehensively } \\
\text { investigated by cellular biologists. } \\
\text { However, recent work demonstrated } \\
\text { what scientists have always known: there } \\
\text { is always more to discover. } \\
\text { Previous research - some of it dating } \\
\text { back over a century - has proven } \\
\text { the existence of mitochondrial } \\
\text { superstructures. These objects are } \\
\text { formed when mitochondria, which } \\
\text { are just } 0.5 \text { microns in length, fuse } \\
\text { to form much larger structures of } \\
\text { five microns or more. For example, } \\
\text { one type of mitochondrial formation, } \\
\text { called nebenkern, was first discovered } \\
\text { in grasshopper sperm. During the } \\
\text { formation of nebenkern, mitochondria } \\
\text { wrap around each other to create a }\end{array}$ \\
\hline
\end{tabular}

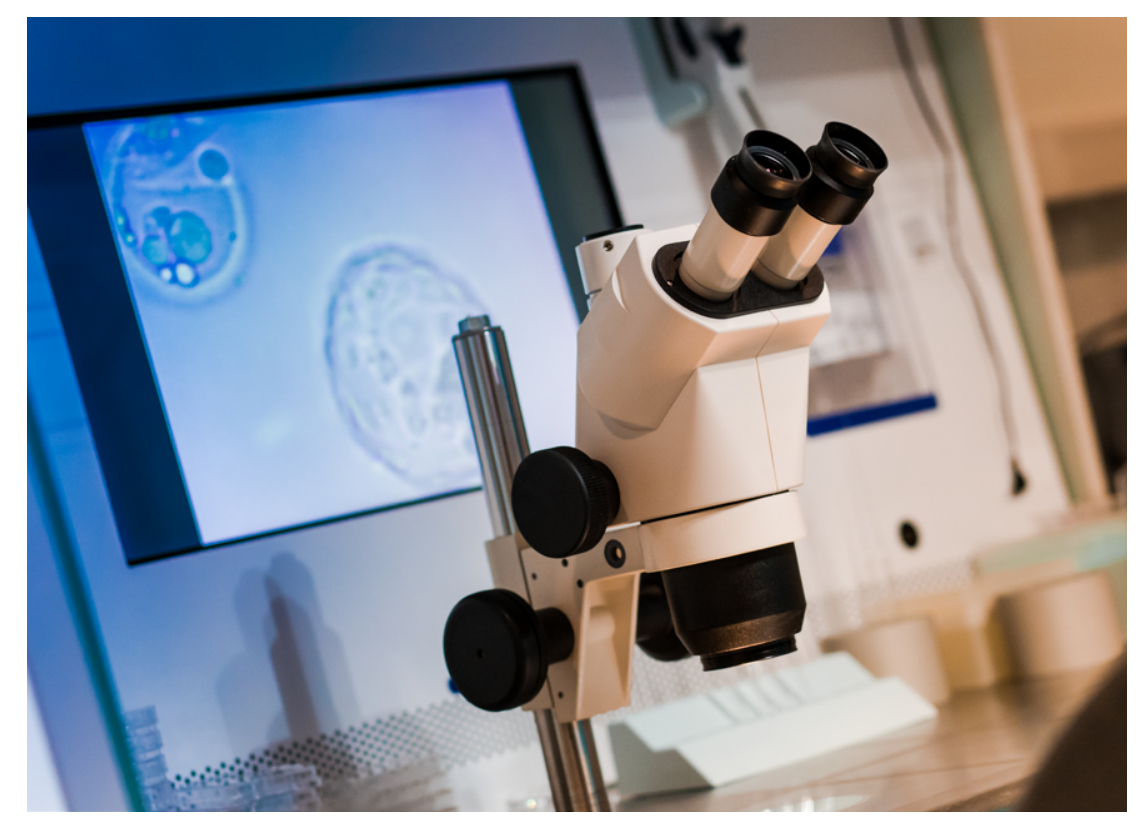

giant spherical structure that is intimately involved in the elongation of the spermatid tail.

MITONUCLEONS: A

MITOCHONDRIAL SUPERSTRUCTURE Dr Honoree Fleming, a biochemist and cell biologit, has been studying cell Ines in vitro for more than 30 years. attention to steroid hormone-dependent differentiation in human endometrial cells sthe type of cell that lines the uterus). During the differentiation process - when cells become specialized, taking on particular cell types with specific roles - mitochondrial superstructures appear to be an essential part of the differentiation process.

Dr Fleming uses the term "mitonucleons" to describe the mitochondrial superstructures that form during endometrial cell differentiation. This name is apt because the structures involve multiple fused genetic material that is normally found in the nucleus of cells.

Mitonucleons form in the first few hours of a 24 to 30 -hour differentiation process that results in the formation of fluidenclosing multicellular hemispheres or domes. The appearance of vacuoles - pockets or spaces - inside the mitonucleon can be detected approximately halfway through the process. Eventually, the entire centre of the mitonucleon appears to be occupied by a gas-filled vacuole whose
origins must result from the release of origins must result from the release of gases during metab

What happens next to domes is both What happens next to domes is both
unexpected and intriguing. Over a unexpected and intriguing. Over a

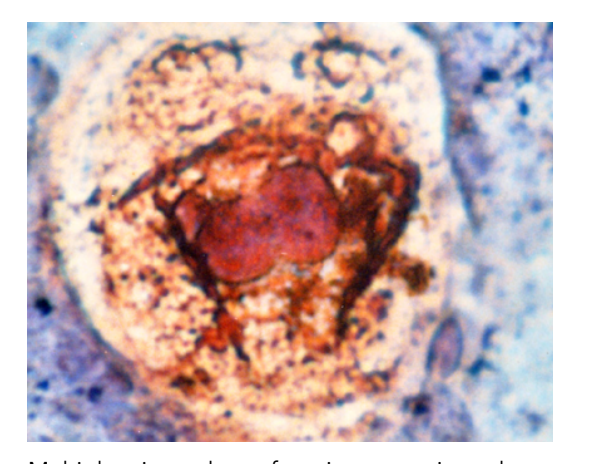

Multiple mitonucleons form in a syncytium when
dome formation is induced in an endometrial epithelial cell culture.

cells (selected for their enhanced domeforming properties) can proliferate to form three-dimensional gland-like structures that appear to be reaching out into the surrounding medium and are capable of secreting materials into the cavity of the dome. Dr Fleming believes this to be an in vitro simulation menstrual cycle as numerous glands are formed in preparation for the implantation of a fertilised egg

\section{FROM THE MITONUCLEON}

\section{TO THE SPHEROID} gland differentiation of human endometrial epithelia, Dr Fleming was one of a small number of scientists studying differentiation of cultured human cells in vitro. In fact, she may have been the only scientist investigating endometrial cell differentiation despite its proven prodigious and essential capacity for that activity progestagen hormones.

Dr Fleming observed biotin-containing mitochondrial enzymes, indicated by a burout chromatin mass. This provided the first indication that a hybrid mitochondrialnuclear organelle was essential for the process that converts the undifferentiated monolayer cells into cells that interact with each other to proliferate out into the medium in glandlike structures.

As happens in the process of discover Dr Fleming began to realise tha mitonucleons could also be observed in single cells in monolayer cultures. As she discovered, the presence of

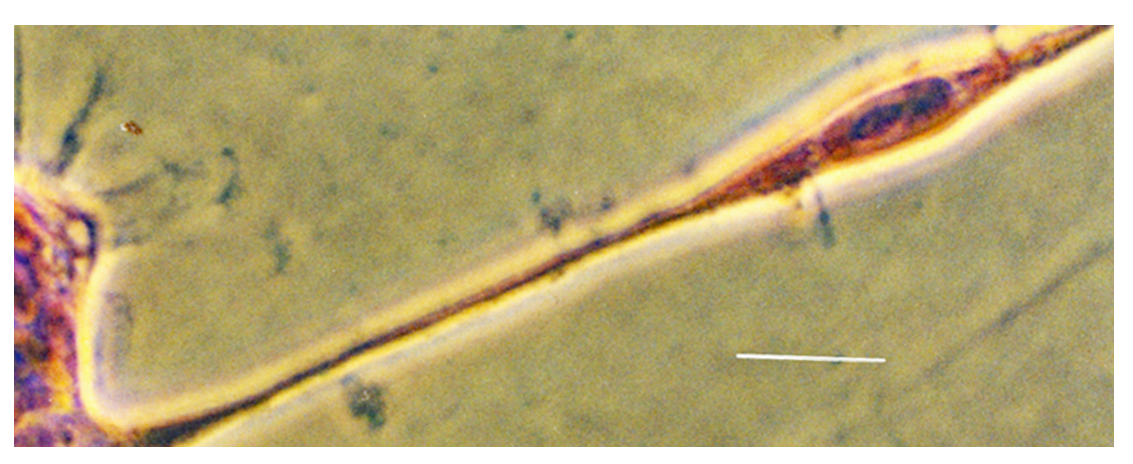

Mitonucleons can squeeze through tubular membrane processes stretching from cells in a solid
spheroid to a colony at the end of the process.

cell results in its detachment from neighbouring cells and ultimately from the petri dish itself. Once again a gas vacuole forms at the centre of the mitonucleon ultimately leading to the formation of a unicellular floating spheroid. This is a single enlarged spherical cell in which the contents of the between the outer membrane of the mitonucleon and the inner membrane of the cell in what amounts to a "rim" of cytoplasm. The resulting structure is a unicellular hollow spheroid.

The expansion of the gas vacuole in the mitonucleon exerts pressure on the cell contents. Where the gas is coming from, however, remains a mystery. Cells normally generate $\mathrm{CO}_{2}$ by any one of number of metabolic pathways. Under

normal circumstances, carbon dioxide is expected to diffuse freely out of the cell. It is possible, however, that there is something about the structure of the mitonucleon that greatly slows down the passage of carbon dioxide.

The unicellular hollow spheroid generated in a polyploid cell by is itself "transitional." Under some circumstances, the free-floating spheroid will re-join the monolayer releasing gaseous bubbles as it reattaches to the petri dish some distance away from where it was generated. In that eventuality, the mitonucleon has contributed to the migration of cells that will eventually lead to their confluence. Or, the

Mitonucleons share characteristics with a group of mitochondrial superstructures called spheroids.

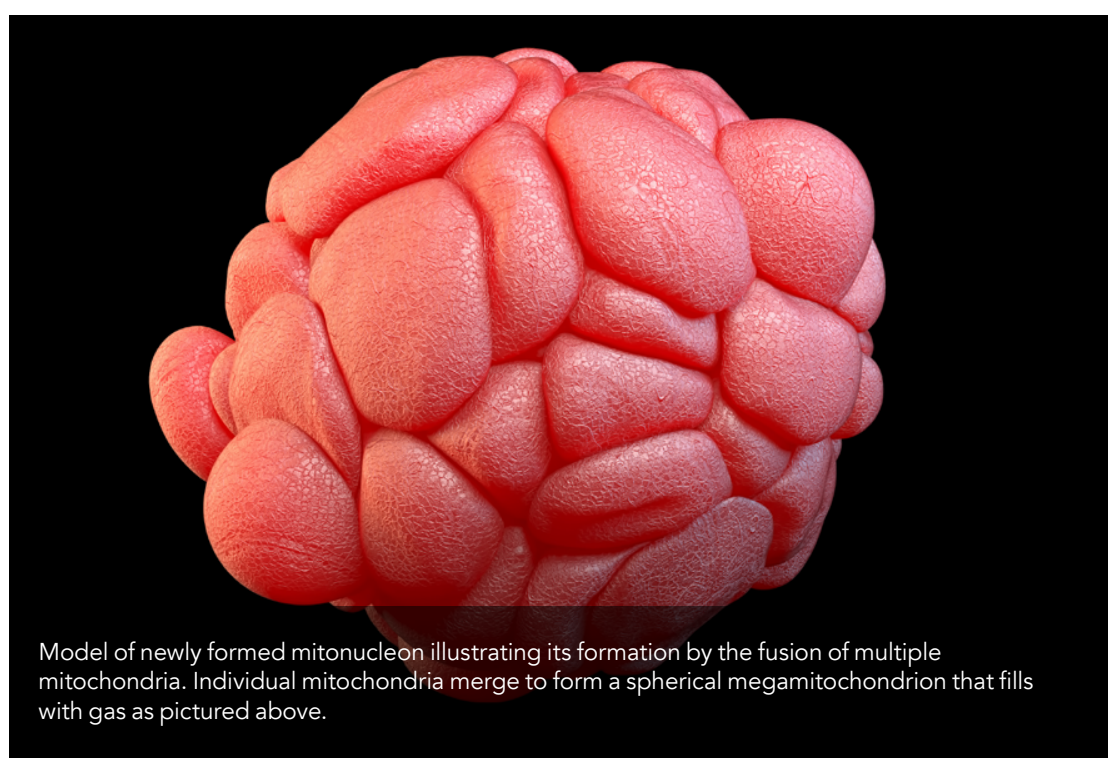




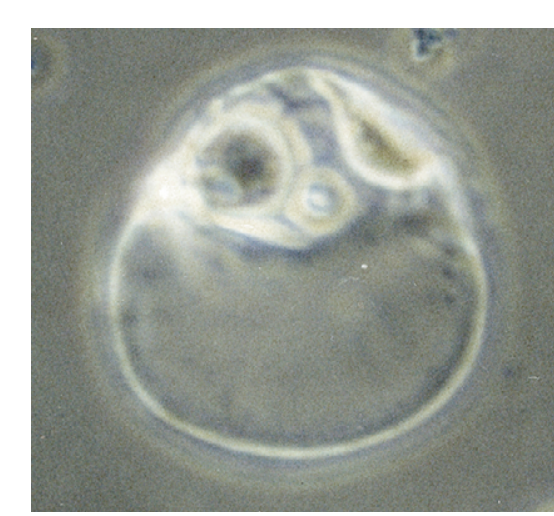

As a cell containing a mitonucleon releases
from a monolayer, the mitonucleon expands compressing chromatin, now detectable as
large polyploid nuclei, as well as cellular cytosos large polyploid nuclei, as well as cellllala crytosal
between the outer membrane of the spherical giant mitoc or
of the cell.

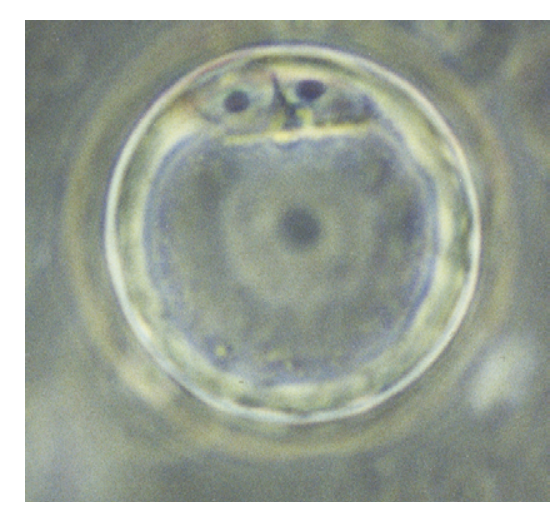
When the process of compression is complete, cytoplasm containing giant nuclei. Pictures of this
and other structures were taken in living cultures. and other structures were taken in living cultures
The structures are therefore unfixed, unstained The structures are therefore unfixed, unstained
and three of the four are of shheriod structures
floating in the medium above a monolayer.

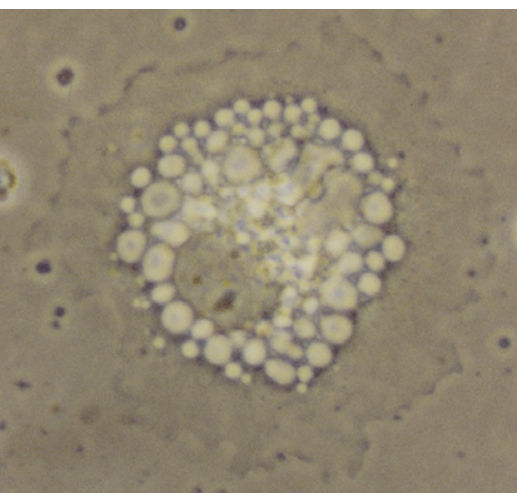

This siant cell is the structure that is not floating.
With the addition of serum, a polyyloid hollow spheroid can reattach to the petrididish as adhering to the surface of the dish. What appears
ab be two giant nuclei can be glimpsed amid to be two giant nuclei can be glimpsed amid
bubbles of gas released from what had been the

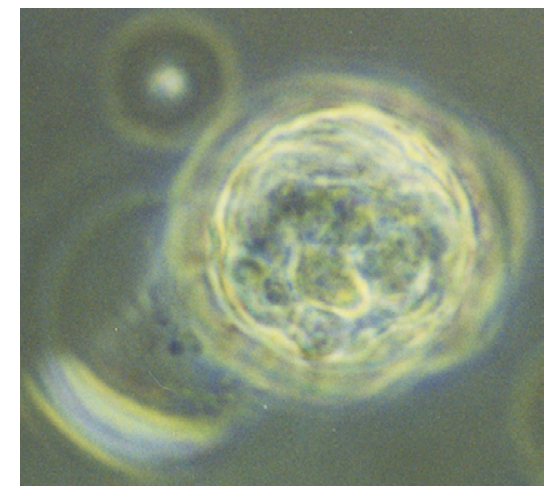

Alternatively, the chromatin in the polyploid
nuclei can fragment into granules that trave through the cytoplasmic rim and reassocites called chromatin streaming that converts th unicecllular hollow spheroid into a multicellular central gas vacuole of the spher

As mitonucleons can generate hollow spheroids, Dr Fleming believes that they are capable of acting as a "cellular trojan horse".

of the hollow spheroid can give rise amitotically to multiple cells filling the cytoplasmic rim and creating the more commonly observed multicellula hollow spheroid.

Dr Fleming suspects that single-celled now spheroids have mostly escaped notice because they are transitiona structures and finding them usually equires looking up into the medium above a monolayer. As opposed to the of spheroid formation inter the process

more research and clinical scientists cancer cells from spheroids are more .

\section{FOLLOWING THE MITONUCLEON} Continuing to look for the distinctive profile of the mitonucleon, Dr Fleming found evidence that mitonucleons are involved in communication of culured endometrial cells with each other. One of the most interesting membrane tubules: extensions of membrane connecting two cells, cels. Dr Flem tubules connect endometrial cells one to another, and also join spheroids to attached endometrial cells.

Dr Fleming ultimately discovered that mitonucleons can pass into, or can form in, tubules leading from spheroids to cells outside of the spheroid. Since tubules carrying mitochondria and/ or nuclei between cells have been described, it is perhaps not surprising to fnd that a transient structure containing mitochondria specifically associated with chromatin can also be exported across significant distances from one cell to another. That mobility, together with the capacity of spheroids to generate multiple cells, makes the mitonucleo something of a "cellular trojan ho

Most recently, Dr Fleming has discovered that clustered single-celled hollow spheroids form from clusters of cells containing mitonucleons. Such clusters seem to have more "staying power" in cultures and appear capable of forming the kinds of membrane tubules that could be invasive if "lodged" in lymph nodes. As she points out in her most recent paper, enough has been discovered about mitonucleons and the "beehive" structures that can be formed to suggest that they constitute one form of the invasive structures responsib for cancer metastases.

\section{CUTTING-EDGE,}

\section{CONTROVERSIAL, OR BOTH?}

This specific research area is currently

somewhat controversial. As yet there

is no clear agreement on the function

or purpose of cell-to-cell tubules, such as those identified in endometrial cells by Dr Fleming. However, these structures are attracting increasing research interest. It is also important to note that some of Dr Fleming's papers on this topic as described here have been published as preprints still to be submitted for peer review and the evidence so far accumulated is based solely on microscopy. Nevertheless, the wealth of new information surely offers a route towards intriguing new avenues implications for high-profile implications for high profle areas

\section{A. Behind the Research}

Dr Honoree Fleming

E: honoree.fleming@castleton.edu E: honoree.fleming@gmail.com

Detail

Bio

Doctoral studies at the University of Chicago led to Honoree Fleming's life-long interest in cell differentiation. Methods to study human endometrial epithelial cell differentiation into gland-like structures in vitro resulted in papers and preprints on a mitochondrial-chromatin superstructure, the mistona mitochinulved in that process

\section{Funding}

NSF Career Advancement award (9210538)

and by an NSF RUI award (9306492)

\section{Collaborators}

lam grateful to have worked with brilliant and motivated undergraduate students at Middlebury and Trinity Colleges.

\section{Bibliography}

Feming, H. (1995). Differentiation in human endometrial cells in monolayer culture: dependence on a factor in fetal bovine serum. Journal of Cellular Biochemistry, 57(2), $262-270$. Fleming, H., Begley, M., Campi, T., Condon, R., Dobyns, K., in differentiating human endomet cells. J. Cel Biochem, 58, 509-516.

Fleming, H., Condon, R., Peterson, G., Guck, I., Prescott, E., Chattield, K. and Duff, M. (1998). Role of biotin-containing endometral cells Jouma of Cellur Biocher. Feming, H. (1999). Structure and function of cultured endometria epithelial cells. Semin Reprod Endocrinol, 17(1), 93-106.

Fleming, H. (2014). Unusual characteristics of opaque Ishikawa endometrial cells include the envelopment of chromosomes with material containing endogenous biotin in the latter stages ittps:/ldo is. PeerJ PrePrints 2:e772v1. Available at: (1) Pleming, H. (2016a). Mitonucleons formed during vacuoles that elevate monolayer syncylia. Differentiation valle Fleming, H. (2016b). Pyknotic chromatin in mitonucleons elevating in syncytia undergo karyorhexis and karyolysis before coalescing into an irregular chromatin mass. Differentiation of at: https://doi.org/10.7287/peeri.preprints.1729v1
Research Objectives

Dr Fleming's work focuses on mitonucleons, a new type of mitochondrial superstructure.

\section{Personal Response}

\section{Do you have any plans to look for mitonucleon}

III I hope other scientists will do so, particularly in tumorous with metastatic cancers. Possible first steps involve using procedures that do not destroy hollow spheroid structures (all of my work suggests that hollow spheroids are delicate) and staining for endogenous biotin. Meanwhile, I continue to study mitonucleons in human endometrial cells, looking for
more evidence for what gases might fill the structures.

Fleming, H. (2016c). Chromatin mass from previously aggregated, pyknotic, and fragmented monolayer nuclei is a source for dome cell nuclei generated by amitosis: Differentiation of Ishikava https://doi.org/10.7287/peer.jprEprints. 1730v1

Fleming, H. (2018a). Polyploid monolayer Ishikawa endometrial cells form unicellular hollow spheroids capable of migration. PeerJ preprints 26793v1 Fleming, H. (2018b). Mitochondrial/Nuclear Superstructures Drive Morphological Changes in Endometrial Epithelia by Pressure Exerted Advances in Bioscience and Biotechnology, 9(5). Available at: https://doi.org/10.4236/abb.2018.95016

Fleming, H. (2019a). Chromatin streaming from giant polyploid amitotic proliferation of nuclei that fill the spheroid envelope. PeerJ Preprints, 7, e27463v1.

Fleming, H. (2019b). Tubular membranes extended between monolayer cells, from solid spheroids, and from clustered hollow granules and mitonucleons. PeerJ Preprints, 7, e27895. 